\title{
Gilding materials and techniques: comparison between altarpieces and their sculptures - a case study
}

\author{
M. Oliveira ${ }^{1,2, *}$ \\ E. Murta ${ }^{1}$ \\ L. Dias $^{2}$ \\ J. Mirão ${ }^{2}$ \\ A. Candeias ${ }^{1}$ \\ 'Laboratório José de Figueiredo, General Directorate of Cultural Heritage, Rua das Janelas Verdes, Lisbon, \\ Portugal \\ ${ }^{2}$ Hercules Laboratory, University of Évora, Largo Marquês de Marialva 8, 7000 Évora, Portugal \\ *carmo.nunes.oliveira@gmail.com
}

\begin{abstract}
We aim to present an analytical study of the materials used in two 17th-18th centuries sculptures Santa Bárbara and Santa Rita de Cássia - and in the altarpiece where they once stood. All the pieces belong to the Church of Nossa Senhora das Mercês in Évora, although today the two sculptures are in the Museum of Évora. The main purpose is to compare the materials and the techniques used in the execution of the gilding and polychrome processes in the three objects. The study is focused on ground layers, gold leaf and polychrome layers. The stratigraphic analyses were performed using optical microscopy on cross-sections and the materials characterization of the different strata resorted to scanning electron microscopy coupled with energy dispersive X-ray spectrometry and to micro-Raman spectroscopy. The results show that the materials and techniques used in the three works of art are very similar and are consistent with the epoch's treatises suggestions.
\end{abstract}

Materiais e técnicas de douramento: comparação entre

altares e as suas esculturas - um caso de estudo

\section{Resumo}

Apresenta-se um estudo analítico dos materiais utilizados em duas esculturas dos séculos XVII-XVIII - Santa Bárbara e Santa Rita de Cássia - e no altar onde ambas figuraram. O altar pertence à Igreja de Nossa Senhora das Mercês, em Évora, e as esculturas encontram-se presentemente no Museu de Évora. O principal objectivo é comparar, entre as três obras, os materiais e as técnicas utilizadas no douramento e na policromia. O estudo foca-se nos estratos preparatórios, na folha de ouro e na camada polícroma. A análise estratigráfica foi realizada por microscopia óptica e a caracterização material dos diferentes estratos recorreu a microscopia electrónica de varrimento acoplada a espectrometria de energia dispersiva de raios $\mathrm{X}$ e a espectroscopia de micro-Raman. Os resultados demonstram que os materiais e as técnicas utilizadas nas três obras são muito semelhantes e são consistentes com as recomendações dos tratados da época.

\section{Keywords}

Baroque

Carved and gilded wood

Polychrome sculpture

Materials characterization

\section{Palavras-chave}

Barroco

Talha dourada

Escultura policromada

Caracterização material 


\section{Introduction}

In Portuguese churches, the quantity of altarpieces often integrating polychrome sculptures testifies to the importance of this type of sacred art, known as talha dourada (gilded carved wood).

The altarpiece and the sculptures presented in this study belong to the church of an extinct convent Nossa Senhora das Mercês (Our Lady of Mercy) that is nowadays the property of the Museum of Évora (ME). The convent was founded in "the first Sunday of July in 1670, where after construction works a new church was erected in February 17th of 1698" [1, p. 37], "but in 1758 [it] still had many incomplete rooms" [2]. The church has richly decorated talha dourada in the main altarpiece, in the two lateral altarpieces and in the arches of the crossing, made by a local carver (Jorge Guerreiro) during a post-earthquake campaign from 1760 [3]. In the transept there are two other altarpieces older but unfortunately no document is known about them or about the sculptures that filled their niches.

The altarpiece, on the side of the gospel in the transept, one of the objects of this study, shown in Figure

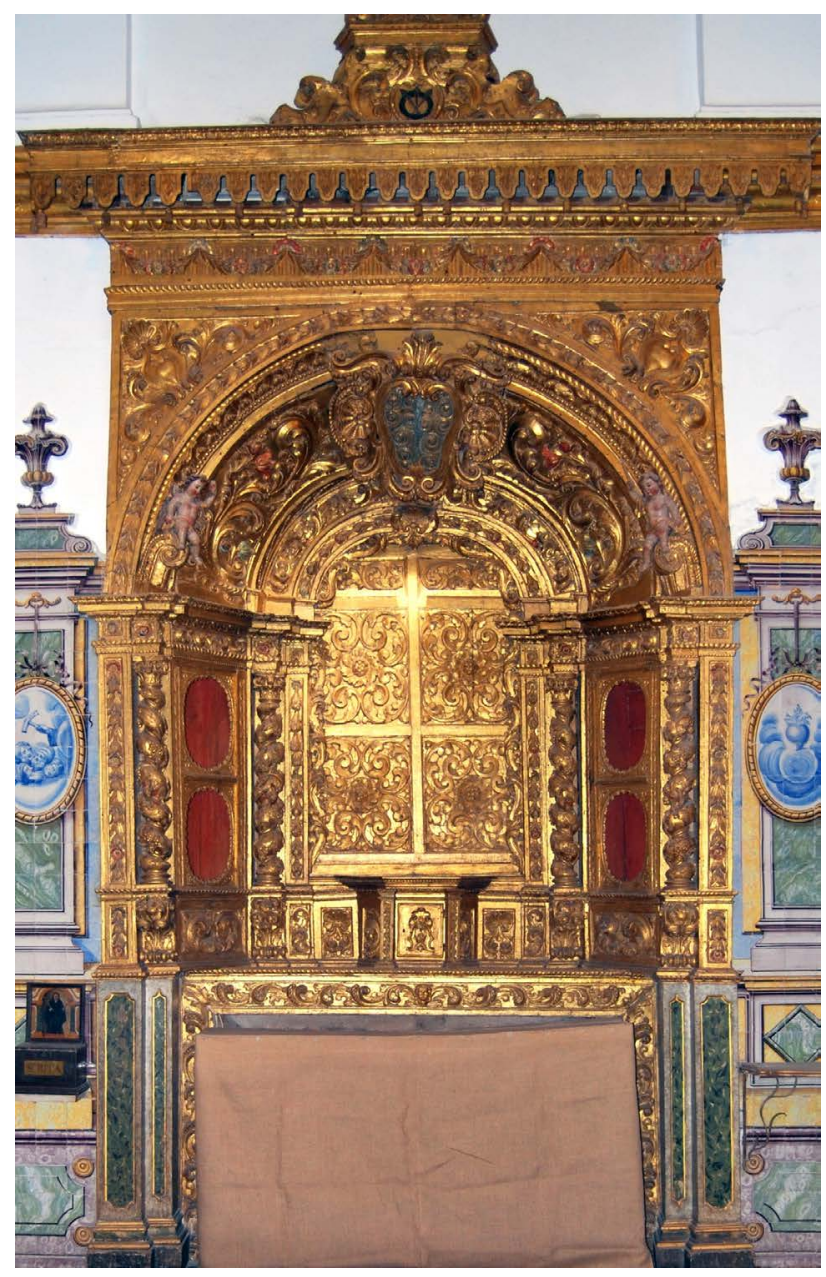

Figure 1. Left altarpiece from the transept of the Church of Nossa Senhora das Mercês.
1, has a concave perspective, one single body and three vertical registers, separated by columns of seven spirals decorated by grapes and phoenixes. The ornamentation, which covers the whole surface, has a naturalist thematic based in flowers and leaves. These are all characteristics typical the Baroque period [4, pp. 95-97]. According to the disposition, the altarpiece was dedicated to a main saint, whose sculpture was placed at the center, and to four other saints, with sculptures in lateral niches, two in each side. Considering the relatively small dimensions of these niches, we deduced that there are only two polychrome sculptures in the ME collection, that belonged to the altarpiece. One of these sculptures, studied in this paper, is a reliquary bust representing Santa Bárbara (Figure 2). The oldest photograph known about this altarpiece was published in a regional inventory from 1966 (Figure 3) and shows a sculpture of Santa Rita de Cássia (Figure 4) standing in the central position. Nevertheless, this does not allow saying for certain that was its original placement. Santa Bárbara and Santa Rita are the two sculptures presented in this study.

Both sculptures have sgraffito as the main decorative technique for the garments, complemented in Santa Rita with punch work. The monochromatic garment and mantle of Santa Rita is associated to her iconography, the simplicity of the nun's habits, reduced to black and some notes of white on the hood and inside the sleeves. The thematic of the estofado work features a flower as the central element, complemented by a range of winding vegetal elements ending in a stylized flower of four petals. The shape of the punch is a propeller with a $1.3 \mathrm{~mm}$ diameter.

In turn, Santa Bárbara's garments have a vaster palette consisting of red, blue, and white. The estofado work seems to be a free-hand sgraffito drawing in opposition to the one projected for Santa Rita, perceived on the symmetrical composition.

This study aims to identify the materials and techniques used in the execution of the gilding and polychrome processes and also compare the results between the sculptures and the altarpiece. Overall, the broader objective is to contribute to a better understanding of this category of art (of which the study is just recently increasing) [5, p.41] and to start grouping dispersed polychrome sculptures in the regional context.

\section{Material characterization}

\section{Experimental}

Microsamples from all different colours present in the altarpiece and in both sculptures were collected and impregnated in epoxy resin - three from the altarpiece (red, green and blue), three from the Santa Bárbara (red, blue and white) and three from Santa Rita (white, black and punch work area), in a total of nine. For a better understanding of the strata, the polished cross 


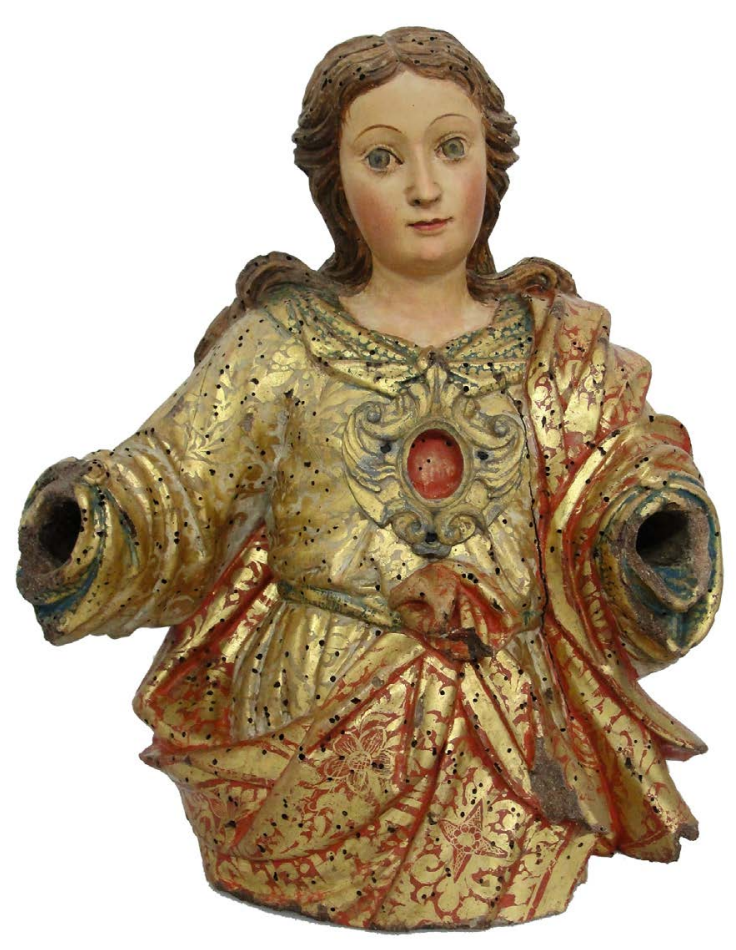

Figure 2. Santa Bárbara sculpture.

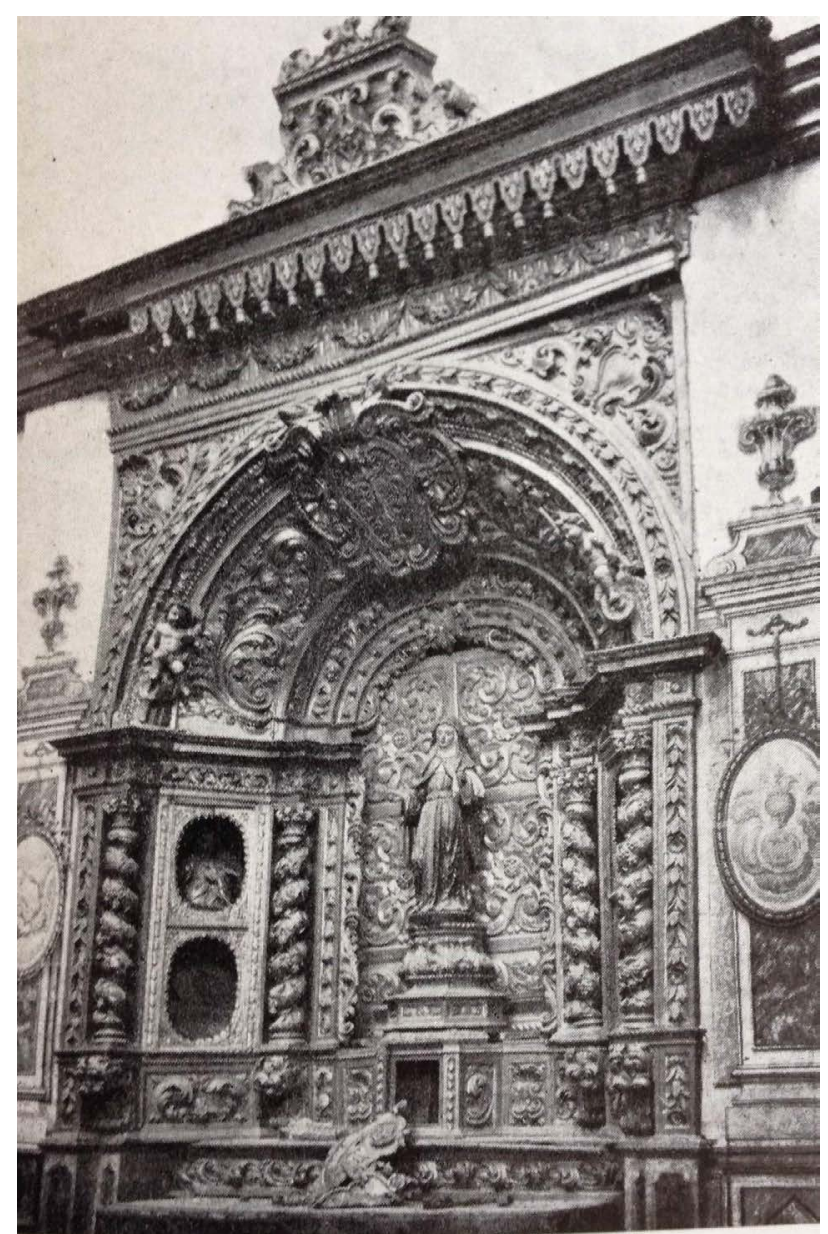

Figure 3. Old photograph showing both sculptures - Santa Rita de Cássia and Santa Bárbara - standing in the altarpiece. sections of the samples were observed with a stereozoom microscope Leica Model DM 2500 M, with a Leica DFC290HD camera for image acquisition, with $20 \times$ and $50 \times$ magnification lenses. The characterization of the materials from the different strata, including ground layers, golf leaf and polychromy, were performed in a SEM HITACHI S-3700N variable pressure scanning electron microscope coupled with a Bruker Xflash 5010 SDD energy dispersive X-ray spectrometer. Micro-Raman spectrometry was also performed on all samples using a Horiba Xplora Raman microscope, with a capacity increased to $100 \times$, and a charge coupled device (CCD) detector. Laser wavelengths of $632.8 \mathrm{~nm}$ and $785 \mathrm{~nm}$ were used. Wavenumber calibration was performed with the Raman peak of a silicon crystal at $520 \mathrm{~cm}^{-1}$. The laser beam was focused on the grains of pigment with $50 \times$ or $100 \times$ objective lenses. The laser power at the surface of the sample was held to $<1.1 \mathrm{~mW}(632.8 \mathrm{~nm})$ and $<6.5$

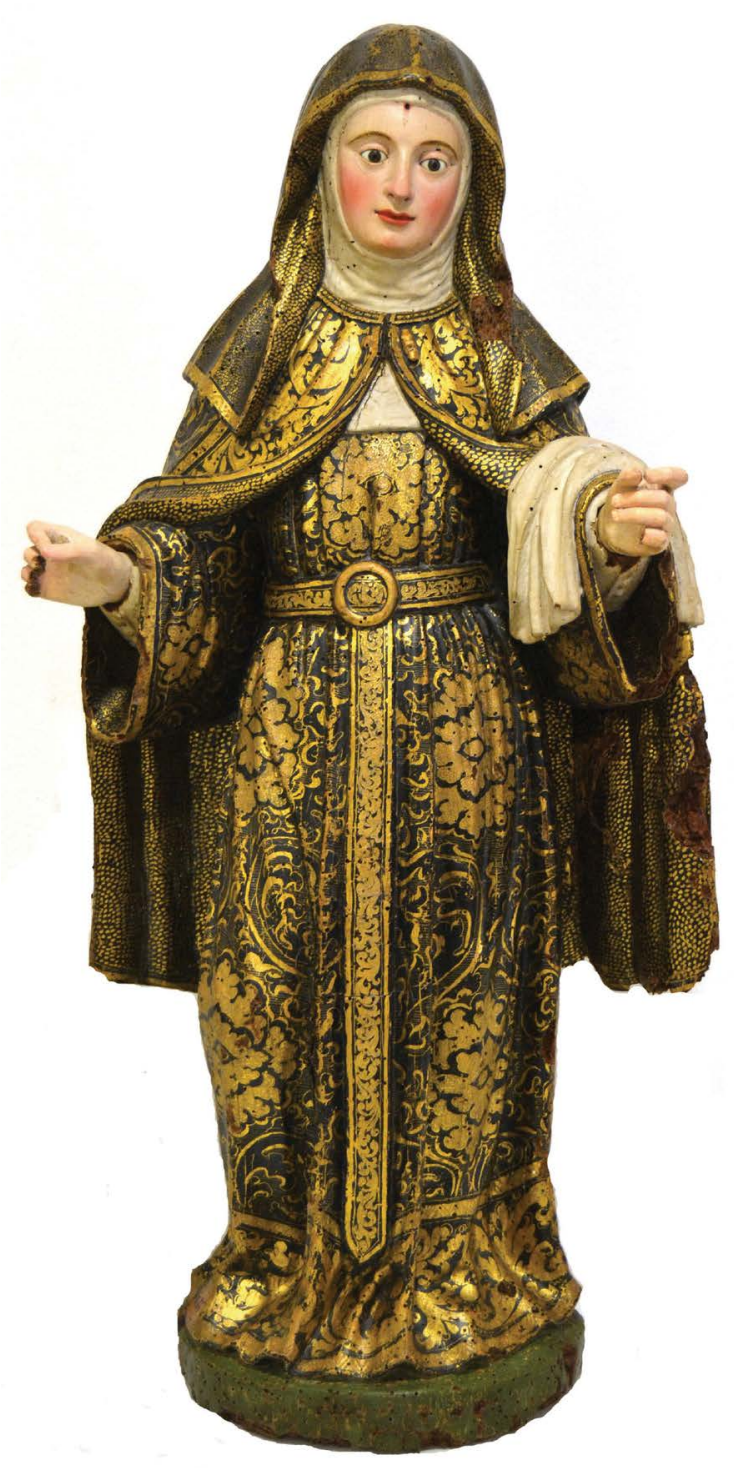

Figure 4. Santa Rita de Cássia sculpture. 
$\mathrm{mW}$ (785 nm). Raman spectra were obtained in scanning mode, after five scans, with acquisition times of 10-20 s.

\section{Results and discussion}

\section{Ground layers}

The ground layer, in both sculptures and in the altarpiece, has a white appearance and covers the whole surface. Although the treatises recommend the use of several layers of two different materials, these were not distinguishable by $\mathrm{OM}$ observation and the maximum thickness registered was around $400 \mu \mathrm{m}$. The analyses made by SEM-EDS, as shown in Figure 5, allow distinguishing two different layers and demonstrate that the first layer, closer to the support, has larger particles comparatively to the second layer; both layers are composed of calcium and sulphur, suggesting calcium sulphate, and these results were consistent for all the analysed samples. In Santa Rita's samples, the second layer showed dolomite inclusions (association of $\mathrm{Ca}$ and $\mathrm{Mg}$ ), as shown in Figure 6. The dolomite inclusions in the second layer of Santa Rita can be, for example: (1) purposely added, if the material used in this layer was an hydrate version of the material used in the first ground, or (2) a natural component, as this material might be from a different origin than the one used in the first layer. In all the samples from the three objects we have also identified dispersed particles of celestite (strontium sulfate), that naturally occurs in gypsum outcrops [5, p. 82].

The micro-Raman analyses showed the presence of anhydrite $\left(\mathrm{CaSO}_{4}\right)$, shown on Figure $7 \mathrm{a}$, and gypsum $\left(\mathrm{CaSO}_{4} \cdot 2 \mathrm{H}_{2} \mathrm{O}\right)$, shown on figure $7 \mathrm{~b}$. Both spectra shown in Figure 7 were obtained in a sample from the altarpiece. The anhydrite layer is the first one above the wood and the gypsum is above the anhydrite layer. The data confirms once more that, in Portugal, in the South [6, p. 75], in the Center [7] and in the North [8, p. 22], these two materials were generally used [9, p. 131] and the recommendations of the paint treatises, such as the one by Filipe Nunes [10, p. 126], were followed in the production of the sculptures. The utilization of two different materials presumes two different goals. The first layer was applied to attenuate the defects of the wooden support [11, p. 239] and the second one creates an ideal surface for the burnished gold leaf [11, p. 241] and for the punch work. A micro-sample collected from a punch work area of Santa Rita's garment analysed by SEM-EDS shows how the gypsum particles got compressed (Figure 8).

\section{Bole layer}

This layer, identical in both sculptures and in the altarpiece, has an orange colour and is applied in all the extension of the gilded areas and with a maximum registered thickness of $40 \mu \mathrm{m}$. The observation of the cross-sections by $\mathrm{OM}$ allowed the identification of two
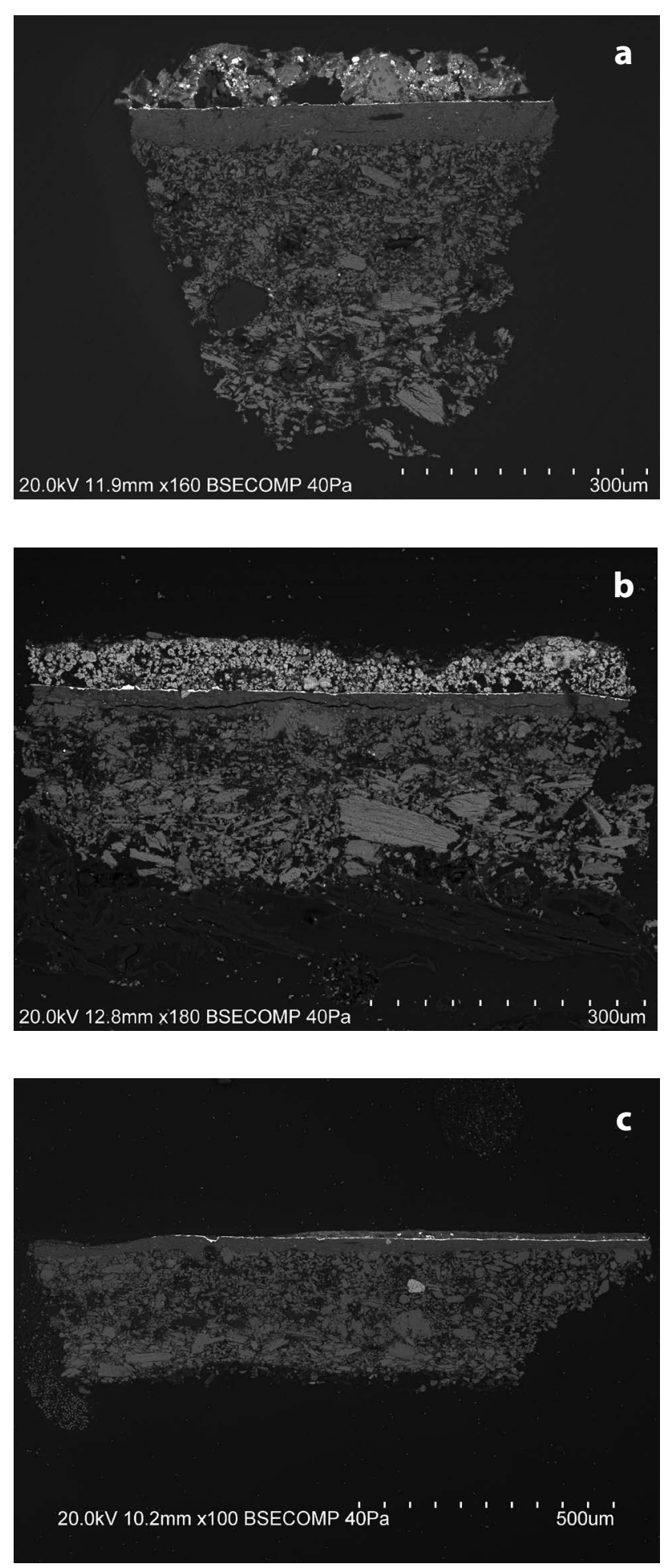

Figure 5. Double structure of the ground layer by backscattering electrons in SEM: a) sample 1 from the Altarpiece collected from a blue area; $b$ ) sample 3 from Santa Bárbara's sculpture collected from a blue area; c) sample 3 from Santa Rita de Cássia's sculpture collected from the black area.

different layers, as shown in Figure 9, through a 20x magnification of a sample taken from a blue area of the altarpiece. The first one is a very homogeneous orange layer, and the second one is mostly orange but with dark particles. With SEM-EDS analysis it was perceptible that 


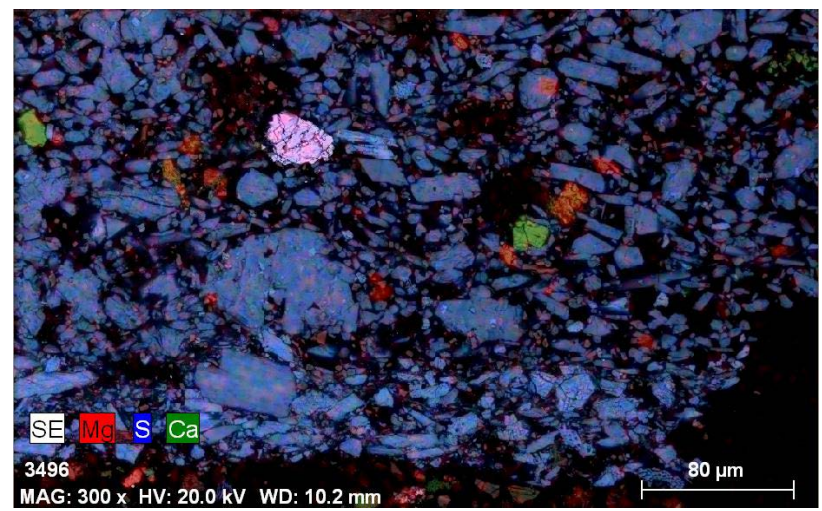

Figure 6. SEM-EDS image of sample 3 from Santa Rita de Cássia showing the magnesium enriched particles $(\mathrm{Mg})$ and celestite (bright particle) inclusions in the gesso mate layer. this layer is composed mainly by iron $(\mathrm{Fe})$, aluminium (Al) and silicon $(\mathrm{Si})$; a few particles of titanium dioxide $\left(\mathrm{TiO}_{2}\right)$ were also traceable, typical of an aluminosilicate containing iron (clay mineral). The dark particles were identified by SEM-EDS analysis as being composed by carbon (C). According to an anonymous recipe from the 17 th century, the bole must be mixed with gypsum and lead pencil to obtain a glossy gilding [12, p. 20]. Plombagina (or graphite) is added to the bole due to its unctuous characteristics which facilitate the friction in the burnishing [13, p. 58]. Francisco Pacheco, a Spanish treatise author from the 17th century, explains that graphite, mixed with the bole makes it softer and satiny, which facilitates the burnish of the gold leaf [14, p. 429]. Even Filipe Nunes, in its 17 th century treatise [10, p.

a

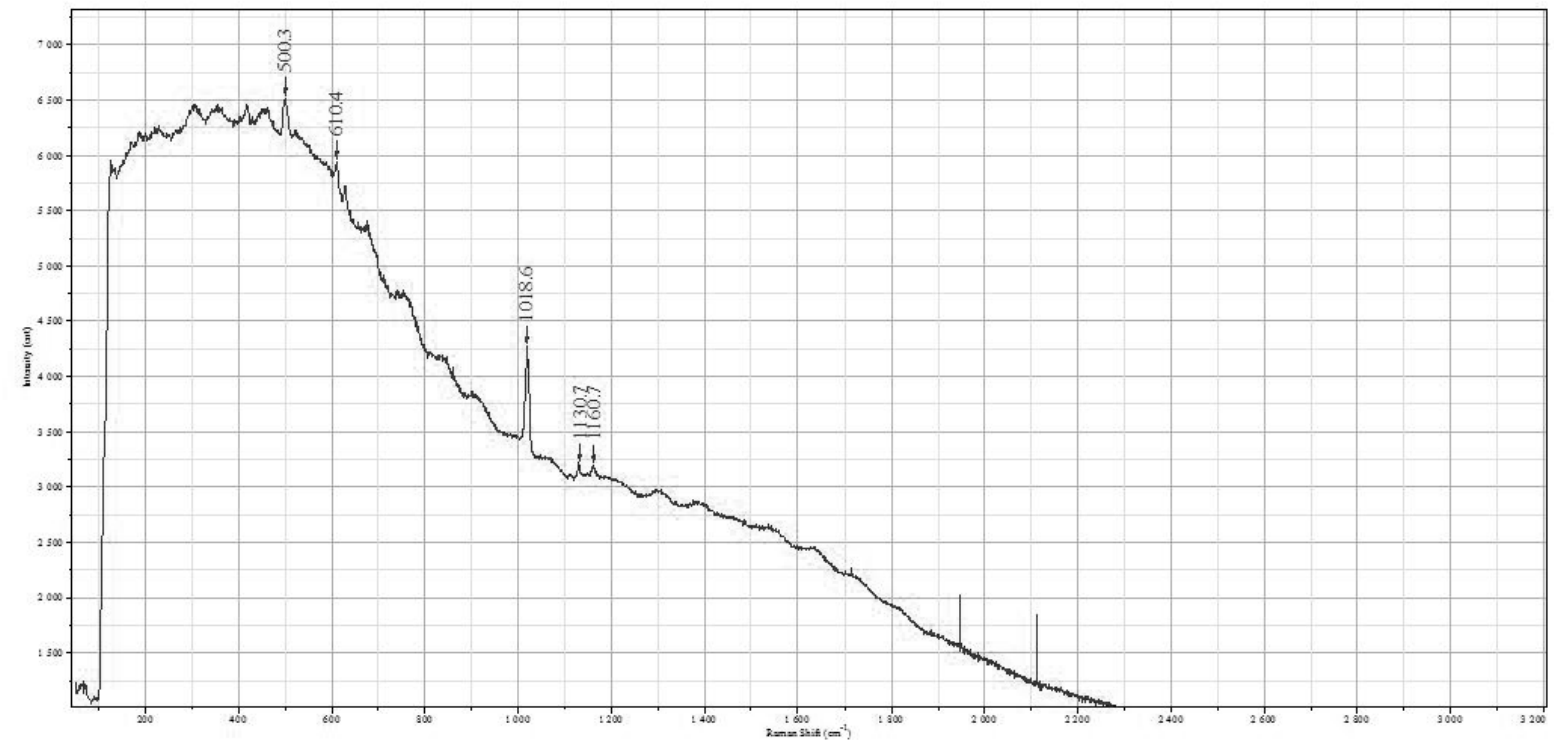

b

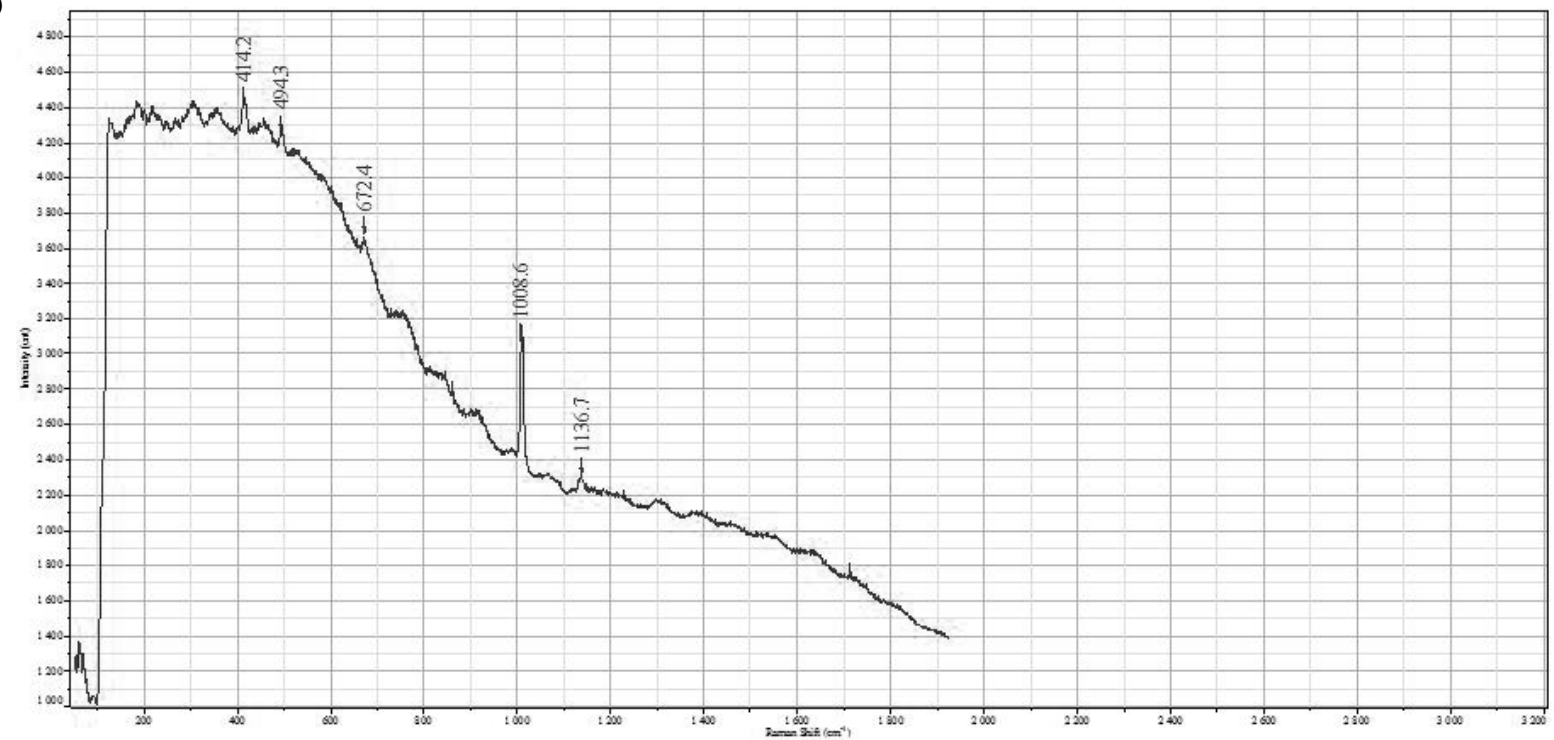

Figure 7. Micro-Raman spectra $(785 \mathrm{~nm}, 6.5 \mathrm{~mW}, 10 \mathrm{~s})$ from sample 1 of the altarpiece: $a)$ anhydrite in the first layer $(500 \mathrm{~m}, 610 \mathrm{~m}$, $1018 \mathrm{vs}, 1160 \mathrm{w})$; b) gypsum in the second layer $(414 \mathrm{~m}, 493 \mathrm{~m}, 670 \mathrm{~m}, 1008 \mathrm{vs}, 1136 \mathrm{~m})$. 


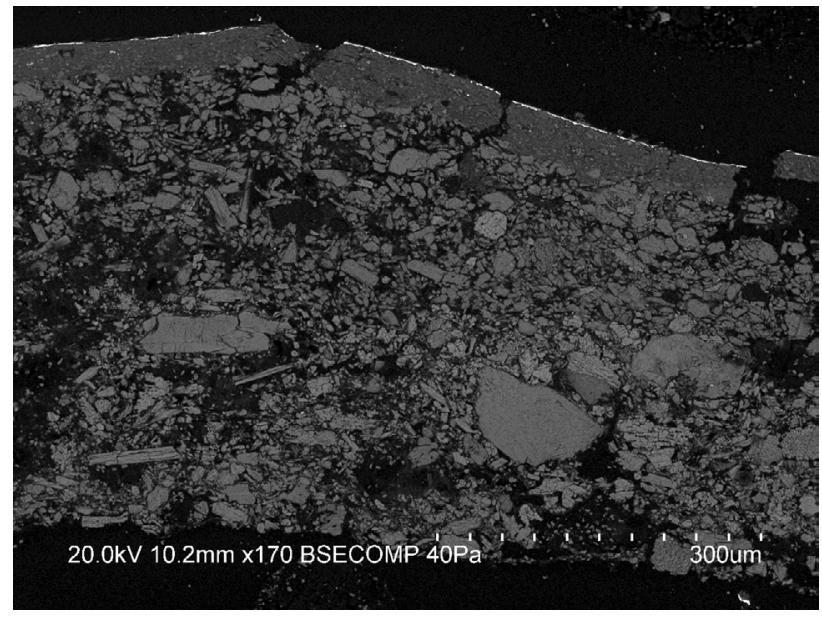

Figure 8. Backscattering electrons image of sample 4 from punch work area of the Santa Rita de Cássia garments, showing the compressed gypsum particles.

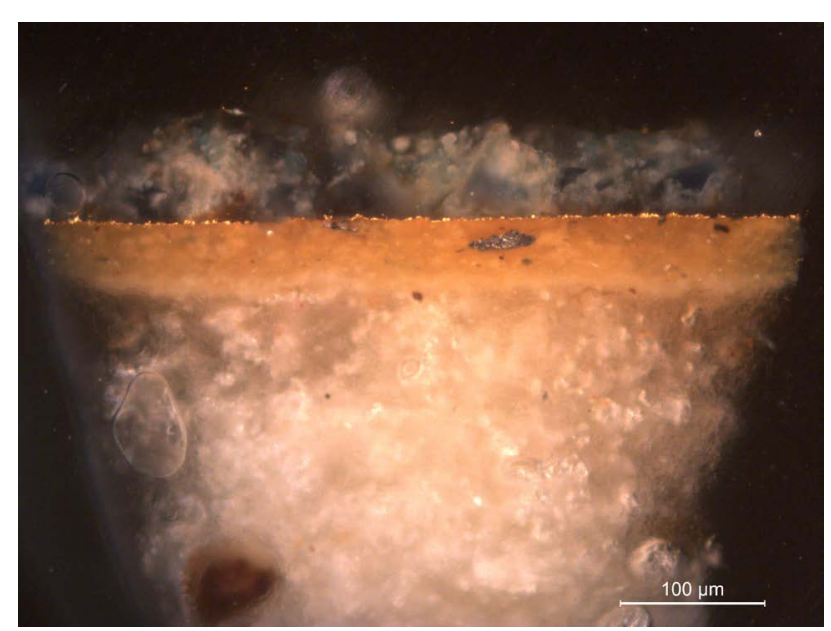

Figure 9. OM $20 \times$ image of sample 1 collected from a blue area of the altarpiece showing the bole layer, where it is possible to differentiate a first homogeneous strata and a second one with the graphite particles.
126], advises the usage of two different boles - a common one first and a refined one afterwards [15, p. 14]. MicroRaman analysis of these dark-grey particles has proven them to be made of graphite (Figure 10). Therefore, we concluded that graphite was intentionally added to the upper layer of the bole, while the first layer remained unadulterated.

\section{Gold-leaf layer}

The gold leaf was applied over the bole layer in the all the garments of Santa Rita, even in the back, in the front garments of Santa Bárbara and in the whole surface of the altarpiece. The alloy identified, by SEMEDS, shows the presence of gold (Au), silver (Ag) and copper $(\mathrm{Cu})$. The semi-quantitative analysis by EDS in different localizations reveals a proportion, on average, of $96 \%$ gold, $3 \%$ silver and $1 \%$ copper. This average demonstrates the utilization of a very high purity gold leaf, of about 23 carats.

\section{Polychrome layer}

As stated before, the polychrome layer covers up all the gold leaf applied in the garments of both sculptures and the decorative drawings are made by removing the paint layer, revealing the subjacent burnished gold leaf (sgraffito technique). In the altarpiece, the sgraffito was used in the flowers and in the body of the phoenixes. Regarding the technique, it is probable that a single stratum of polychromy was applied, which varies from 16 to $30 \mu \mathrm{m}$. It is visible, through OM and SEMEDS, that all the colours are composed of a mixture of pigments, as opposed to a single pigment, except for the red - composed of vermilion - and the blue of Santa Bárbara.

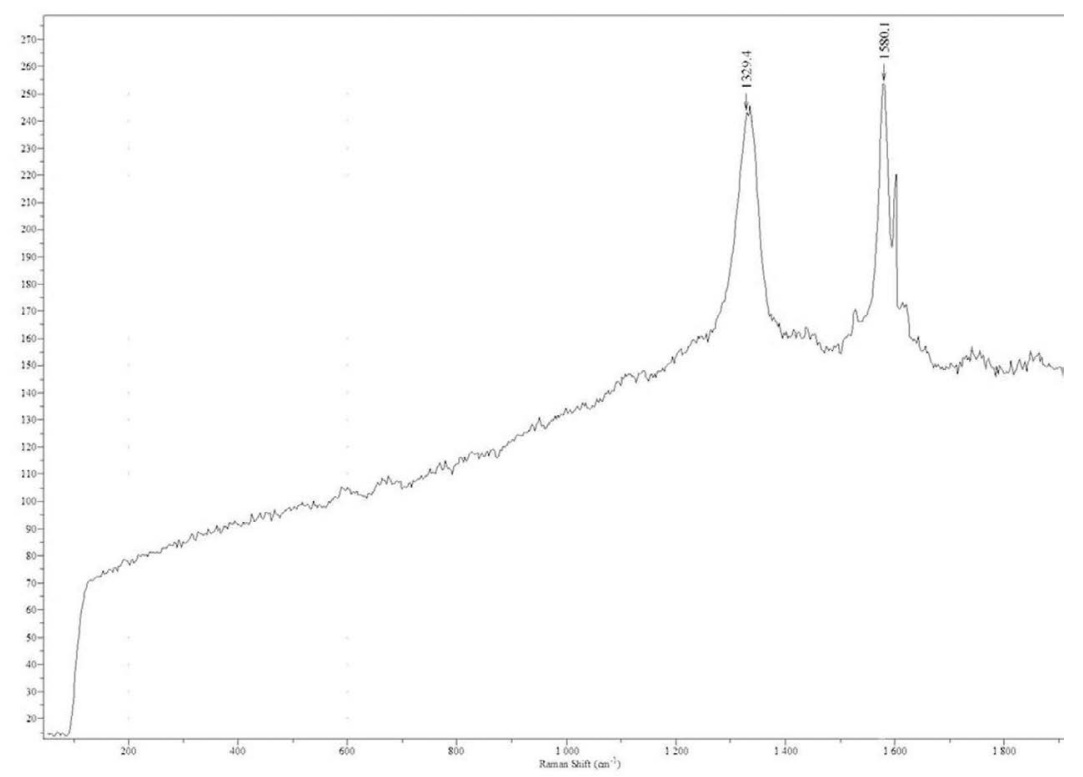

Figure 10. Micro-Raman spectra (638 nm, $1.1 \mathrm{~mW}, 5 \mathrm{~s})$ of sample 3 from Santa Rita de Cássia identifying graphite (1326s, 1582vs). 

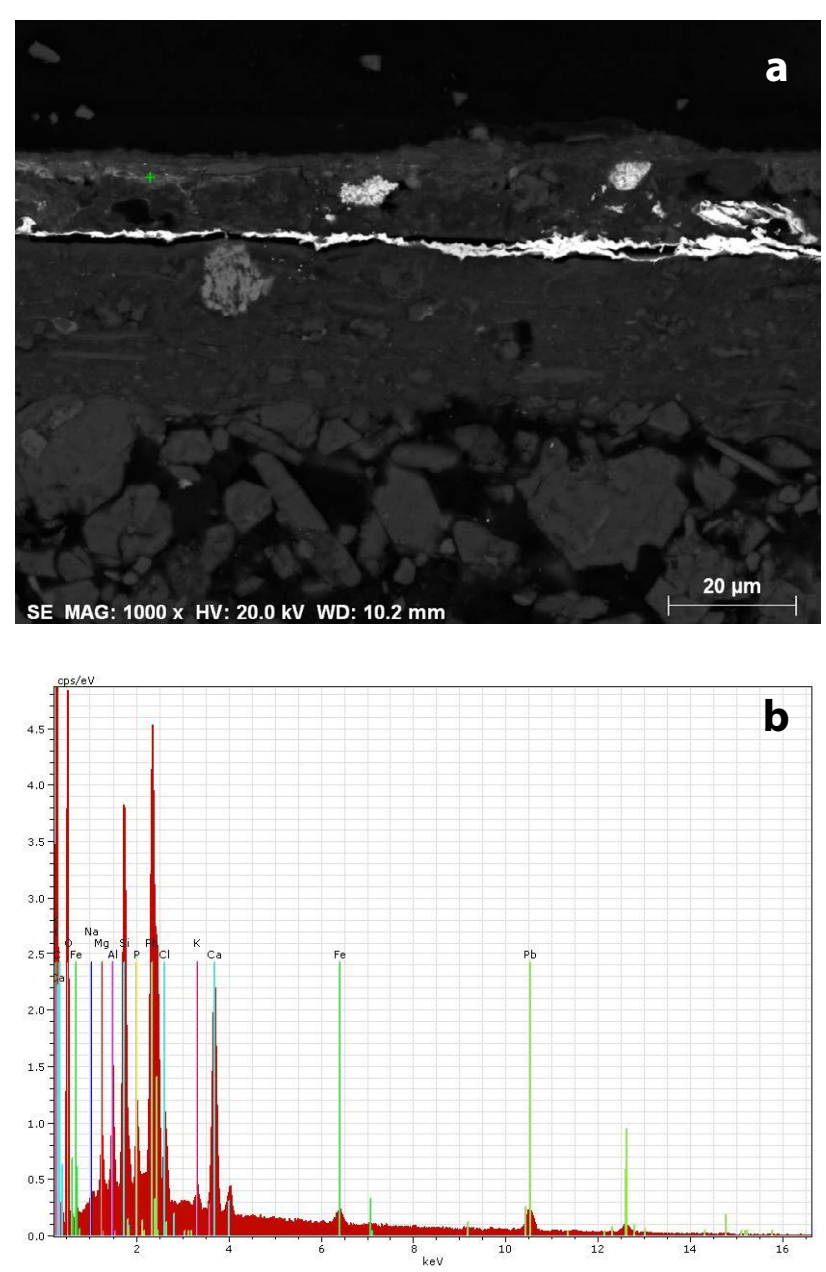

Figure 11. a) Backscattering electrons image of sample 3 from Santa Rita de Cássia black garments; $b$ ) EDS spectrum of point analysis showing calcium phosphate.

Santa Rita has just two different colours - black and some white details. The black layer is composed of a mixture of elements such as calcium, iron and lead; the spot analyses made by EDS show calcium phosphate as the main colour, as shown on Figure 11. The white layer is a mixture of white lead and calcium carbonate.

In turn, Santa Bárbara has three different colours in the garments - red, white and blue. For the red colour, mercury was detected, confirming the use of vermilion (mercury sulphide), as shown in Figure 12a; for the white, a mixture of lead white and calcium carbonate was found, as shown in Figure 12b. Copper was detected in the blue layers, confirming the use of azurite (copper basic carbonate), as shown in Figure $12 \mathrm{c}$.

For the altarpiece, mercury was detected in the red, confirming the use of vermilion. The blue layers were obtained by mixing smalt (angular irregular particles composed of $\mathrm{Si}, \mathrm{K}, \mathrm{Co}, \mathrm{As}$ ), azurite ( $\mathrm{Cu}$ detected), lead white and calcium carbonate, as shown in Figure 13.
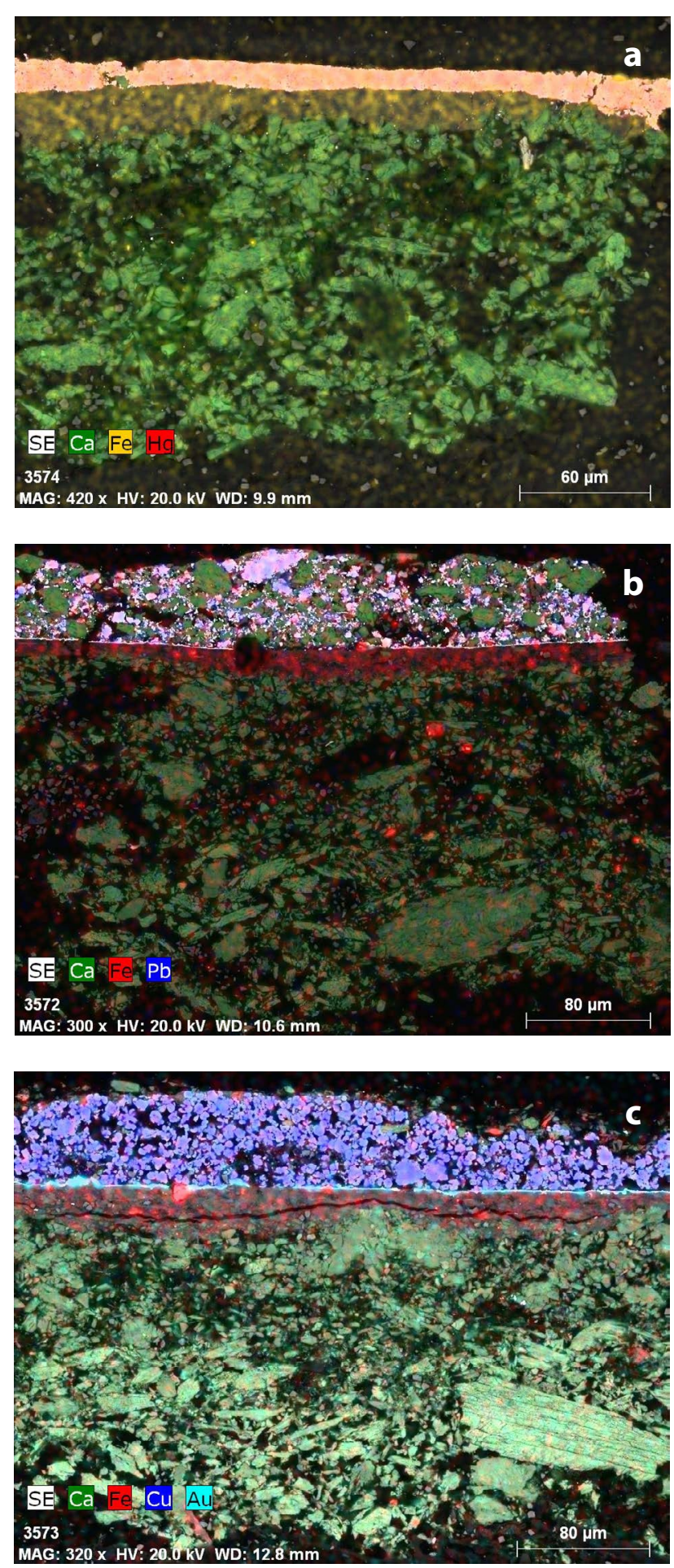

Figure 12. SEM-EDS images of samples 1 (red), 2 (white) and 3 (blue) collected from the Santa Bárbara garments: $a$ ) vermilion identified by $\mathrm{Hg} ; b$ ) calcium carbonate and lead white mixed for the white color; $c$ ) azurite identified by $\mathrm{Cu}$ for the blue color.

Copper was also identified in the green layers, but the results for the copper-based pigment were not conclusive by micro-Raman. 

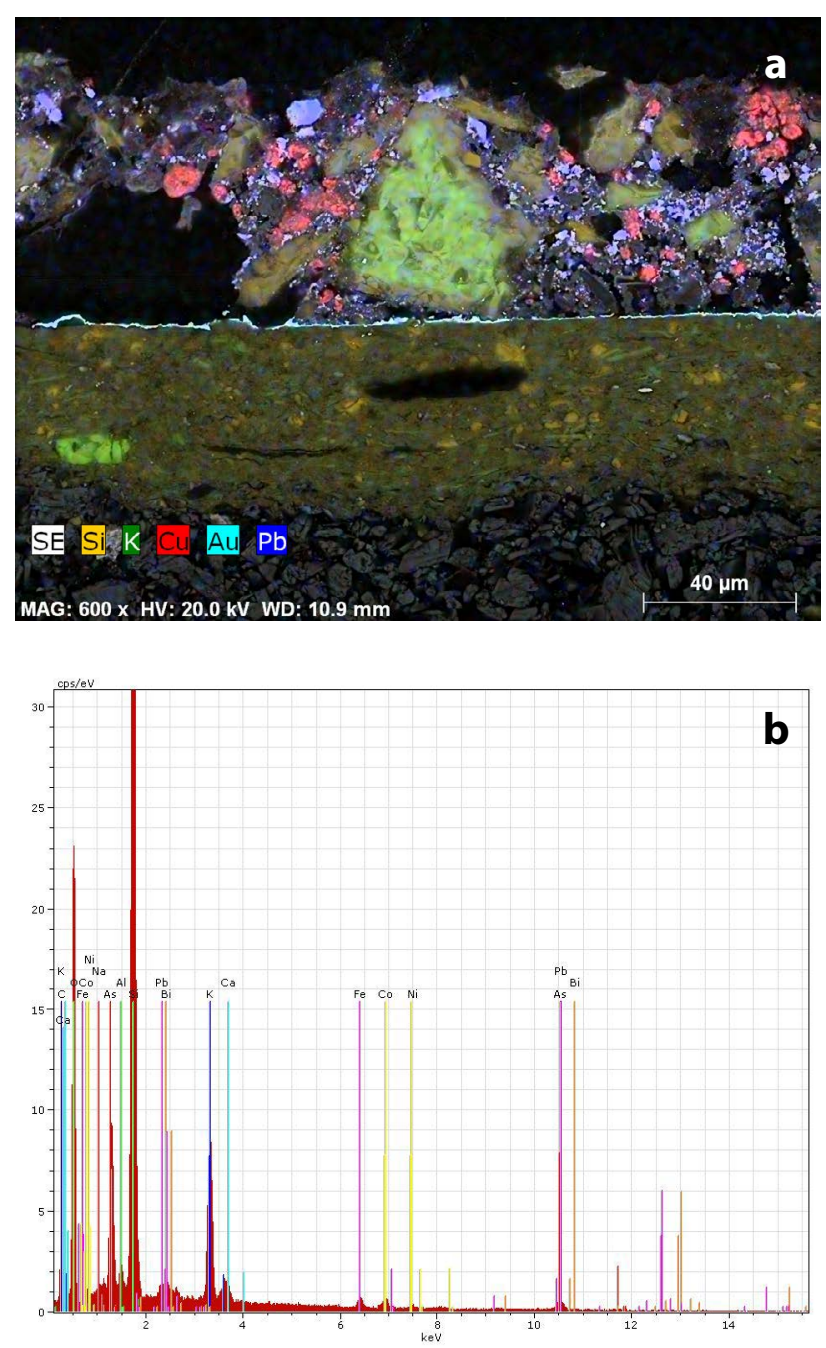

Figure 13. a) SEM-EDS image of sample 1 collected from a blue area of the altarpiece; $b$ ) EDS spectrum of point analysis showing smalt identified by $\mathrm{K}, \mathrm{Si}$, Co.

\section{Conclusion}

The present case study revealed that the materials and techniques identified are, generally, in correspondence with the epoch's recommendations and the published studies about Portuguese polychrome sculpture and altarpieces in talha dourada. The results showed that both sculptures and the altarpiece are very similar regarding major components used in the different strata of the gilding work. The materials identified in all the layers for the three objects are in consonance with each other: anhydrite in the gesso grosso layer; gypsum in the gesso mate layer; aluminosilicate containing iron in the bole layer, with addition of graphite; the high purity of the gold leaf; and the single layer of colour paint to define the main colour, mainly with combined pigments, except for the reds and one of the blues. In the case of the Santa Rita de Cássia, a slight difference is observed in the composition of the ground layer, namely given the dolomite inclusions of the gesso mate layer.
More research will be undertaken in order to identify all the materials used in the gilding and polychrome processes, like the binders of the layers and the remaining pigments. We also expect to extend this study to other altarpieces and polychrome sculptures from the region of Alentejo in order to obtain more systematized results.

\section{Acknowledgements}

This study was developed under a research grant (SFRH/ BI/51521/2011) provided by Fundação para a Ciência e Tecnologia.

\section{References}

1 Maria, Fr. A. S., Sanctuario Mariano, Tomo VI, Lisboa Occidental (1716).

2 'Paróquia de Santo Antão', in Memórias Paroquiais 1758, entro Interdisciplinar de História, Culturas e Sociedades da Universidade de Évora, http://portugal1758.di.uevora.pt/index.php/component/customproperties/tag/transcript (accessed 2015-03-27).

3 Espanca, T., Inventário Artístico de Portugal - Concelho de Évora, Academia Nacional de Belas-Artes, Lisboa (1966).

4 Lameira, F., O Retábulo em Portugal - das Origens ao Declínio, Universidade do Algarve - Universidade de Évora, Faro-Évora (2005).

5 Coroado, J.; Antunes, V.; Serrão, V.; Oliveira, M. J.; Dias, L.; Candeias, A.; Mirão, J.; Carvalho, L.; Seruya, A. I., 'Presença de celestite nos retábulos portugueses', in As Preparações na Pintura Portuguesa. Séculos XV e XVI, ed. V. Serrão, V. Antunes and A. I. Seruya, Faculdade de Letras da Universidade de Lisboa, Lisboa (2013) 75-83.

6 Cardoso, I., '18th century church altarpieces in the Algarve, Portugal: a comparison of the historical documents to the results of microscopical analysis', Infocus 4 (2006) 64-86.

7 Sandu, I.; Murta, E.; Ferreira, S.; Pereira, M. C.; Candeias, A.; Mirão J.; Miguel, C.; Paba, F., 'More than gold - an interdisciplinary, complementary study of gilding materials and techniques in Baroque altarpieces from Portugal', ECR - Estudos de Conservação e Restauro 6 (2015) 13-37, doi:10.7559/ecr.6.7522.

8 Barata, C., Cruz, A. J.; Carballo, J.; Araújo, M.E., 'The materials and techniques of polychrome baroque wooden sculpture: three works from Baião, Portugal', International Journal of Conservation Science 1(1) (2010) 19-26, http:// www.ijcs.uaic.ro/volume_1.html (accessed 2015-12-21).

9 Serck-Dewaide, M., 'Les techniques utilisées dans l'art baroque religieux des XVIIe et XVIIIe siècles au Portugal, en Espagne et en Belgique', in Policromia. A Escultura Policromada Religiosa dos Séculos XVII e XVIII. Estudo Comparativo das Técnicas, Alterações e Conservação em Portugal, Espanha e Bélgica, ed. A. I. Seruya, Instituto Português de Conservação e Restauro, Lisboa (2002) 119155.

10 Nunes, F., Arte da Pintura, Editorial Paisagem, Porto (1982). Original 1615.

11 Gómez, S. 'Las preparaciones de yeso en la pintura sobre tabla de la escuela española.', $\mathrm{PhD}$ dissertation, Faculdad de Bellas Artes, Universidad Complutense de Madrid (2005), http://eprints.ucm.es/7267/ (accessed 2015-12-21).

12 Ferreira-Alves, N. 'O douramento e a policromia no Norte de Portugal à luz da documentação dos séculos XVII e XVIII', in Policromia. A Escultura Policromada Religiosa dos Séculos XVII e XVIII. Estudo Comparativo das Técnicas, 
Alterações e Conservação em Portugal, Espanha e Bélgica, ed. A. I. Seruya, Instituto Português de Conservação e Restauro, Lisboa (2002) 17-22.

13 Tejeda, Laura. 'El oro en hoja: aplicación y tratamiento sobre soportes móviles tradicionales, muro y resinas', $\mathrm{PhD}$ dissertation, Faculdad de Bellas Artes, Universidad Complutense de Madrid (2001), http://eprints.ucm.es/7082/ (accessed 2015-12-21).

14 Bruquetas, R., Técnicas y Materiales de la Pintura Española en los Siglos de Oro, Fundación de Apoyo al Historia del Arte Hispánico, Madrid (2002).

15 Barata, C., 'Caracterização de materiais e técnicas de policromia da escultura portuguesa sobre madeira de produção erudita e popular da época barroca', Master dissertation, Faculdade de Ciências, Universidade de Lisboa (2008), http://hdl.handle.net/10451/1243.
Received: 2015-07-07

Revised: 2015-11-09

Accepted: 2015-12-21

Online: 2016-01-04

This work is licensed under the Creative Commons Attribution-NonCommercial-NoDerivatives 4.0 International License. To view a copy of this license, visit http://creativecommons.org/licenses/by-nc-nd/4.0/deed.en. 
